\title{
THE DECOMPOSITION PROCESS OF INSURANCE OPERATIONS
}

\author{
Lech GĄSIORKIEWICZ
}

Warsaw University of Technology, Faculty of Management, Warsaw, Poland

e-mail: l.gasiorkiewicz@wz.pw.edu.pl

\begin{abstract}
This study sets out an original concept of the decomposition process of insurance operations. The first part of the paper presents the concept of the process, the process-based approach and process management. The further part identifies the processes carried out in insurance companies and discusses the purposes of implementing them. The final part of the study presents an example of the practical application of the process-based approach to issues of financial management of an insurance company.
\end{abstract}

Keywords: process, process-based approach, process management.

1

\section{Introduction}

Insurance companies are an important part of the financial market, which is now facing an ever more competitive struggle, and a need for more and more risk protection. The activities of insurance companies in these conditions require a new approach. This study assesses that the process-based approach to insurance activity is adequate for the conditions for changes in the insurance business environment. It provides for consistent foundations for many observations on the financial management of insurance companies; it enables the decision-making processes to be tracked, to monitor the legitimacy of costs incurred; it sets out conditions for generating accurate and important - both strategically and operationally - cost information, including on the processes and activities undertaken.

\section{Processes, process-based approach and process management}

The functioning of any organisation can be presented by showing a group of interrelated processes, organisation, while minimising the operating costs of these processes. This approach offers the greatest potential for improving the effectiveness and cooperation between organisational units pursuing the process, and enables the whole organisation to function more efficiently [1, pp. 14-15]. The literature reveals a number of definitions of the concept of process. T. Pszczółkowski defines a process 'as a series or a range of events occurring in time and treated as a whole due to certain distinctive features' [12, p. 185]. According to J. Zieleniewski, 'a process is many consecutive events that are interdependent in some way' [16, p. 16]. According to M. Porter, 'a process is a val- ue chain in which the amount involved in the creation or delivery of a product or service increases through the implementation of various activities. Each subsequent activity performed in the process should be adding a new value to the effect of prior activities' [11, p. 3]. According to P. Grajewski, 'a process is a set of sequential steps that are interrelated with cause-effect relationships. The results of the preceding actions are the input of the subsequent ones. Every action or set of actions can be described as a process by which a certain initial value (effort) brings about a result (volume converted, enriched with added value), which is the result of the process' [5, p. 55]. M. Trocki, M. Romanowska define processes 'as sets of activities implemented in the organisation in cause-effect relationships, carried out to achieve the pursued objective by teams of performers at many workplaces, in many organisational units' [13, p. 64]. J. Brilman defines a process 'as a set consisting of a sequence of operations performed to achieve pre-determined results' [2, p. 287]. According to E. Skrzypek and M. Hofman 'a process is a logical sequence of consecutive or concurrent actions, the implementation of which leads to meeting customer expectations, both internal and external, by providing him with a product, service or documentation in accordance with his requirements' [14, p. 12]. K. Perechuda defines a process 'as a set of concurrent tasks running in parallel, conditionally or sequentially, leading to changes in the assets of a company from the input to the final results in the form of a product or service' [10, p. 88].

Gathering from the above definitions, the authors most often define a process as a sequence of actions (operations) performed in parallel or sequentially, conditionally, which aim to produce a product or service. 
Table 1. Differences between the traditional and the process-based approach to business management (source: [13, pp. 10-11])

\begin{tabular}{|l|l|l|}
\hline \multicolumn{1}{|c|}{ Characteristics } & \multicolumn{1}{|c|}{ Static aspect } & \multicolumn{1}{c|}{ Dynamic aspect } \\
\hline Term & Structural Management & Process Management \\
\hline $\begin{array}{l}\text { Elementary } \\
\text { management objects }\end{array}$ & Workplaces & Work operations \\
\hline $\begin{array}{l}\text { Complex } \\
\text { management objects }\end{array}$ & $\begin{array}{l}\text { Organisational units as a grouping of work } \\
\text { positions: lines, sections, branches, units, } \\
\text { divisions, offices, levels, departments }\end{array}$ & $\begin{array}{l}\text { Processes as a grouping of opera- } \\
\text { tions: phases of processes, partial } \\
\text { processes, processes, complexes } \\
\text { of processes }\end{array}$ \\
\hline $\begin{array}{l}\text { Component } \\
\text { of management }\end{array}$ & $\begin{array}{l}\text { Functions as groupings of repetitive tasks, } \\
\text { people as employees of organisational units, } \\
\text { resources as resources of organisational units }\end{array}$ & $\begin{array}{l}\text { Tasks as a series of actions, people } \\
\text { as participants in the processes, } \\
\text { resources as means of process im- } \\
\text { plementation }\end{array}$ \\
\hline
\end{tabular}

At the same time, they emphasise the need to meet the internal and external expectations of the customer, as well as indicate the need for order, to organise activities in time and space.

Targeting an organisation (a company, an institution) towards the processes occurring in it is called the process-based approach or orientation. This approach assumes that each entity is a set of mutually interwoven processes, whose identification allows a better understanding of value creation, where streamlining and continuous improvements increase the effectiveness of the enterprise and customer satisfaction [9, p. 40].

A process-based approach to managing business organisations (process-based management) is currently the dominant paradigm in management. It is characterised by changing from the classic perception of the organisation, which is based on the logic of specialisa- tion and grouping similar functions to try and create larger units i.e., changing into a new organisation focused on gathering resources from various areas around building value for their customers. In this approach, the processes are the basis for the allocation of tasks, resources, for development, training, evaluation and rewarding of employees [1, p. 17].

Differences between the traditional and the processbased approach to business management are shown in Table 1.

Process management is defined as a comprehensive and systematic continuous use of influence concepts, methods and tools of influence on the processes taking place in the organisation, aimed at achieving the goals of the organisation and best meeting the needs of its external and internal customers [9, p. 57]. A process management diagram is shown in Fig. 1.

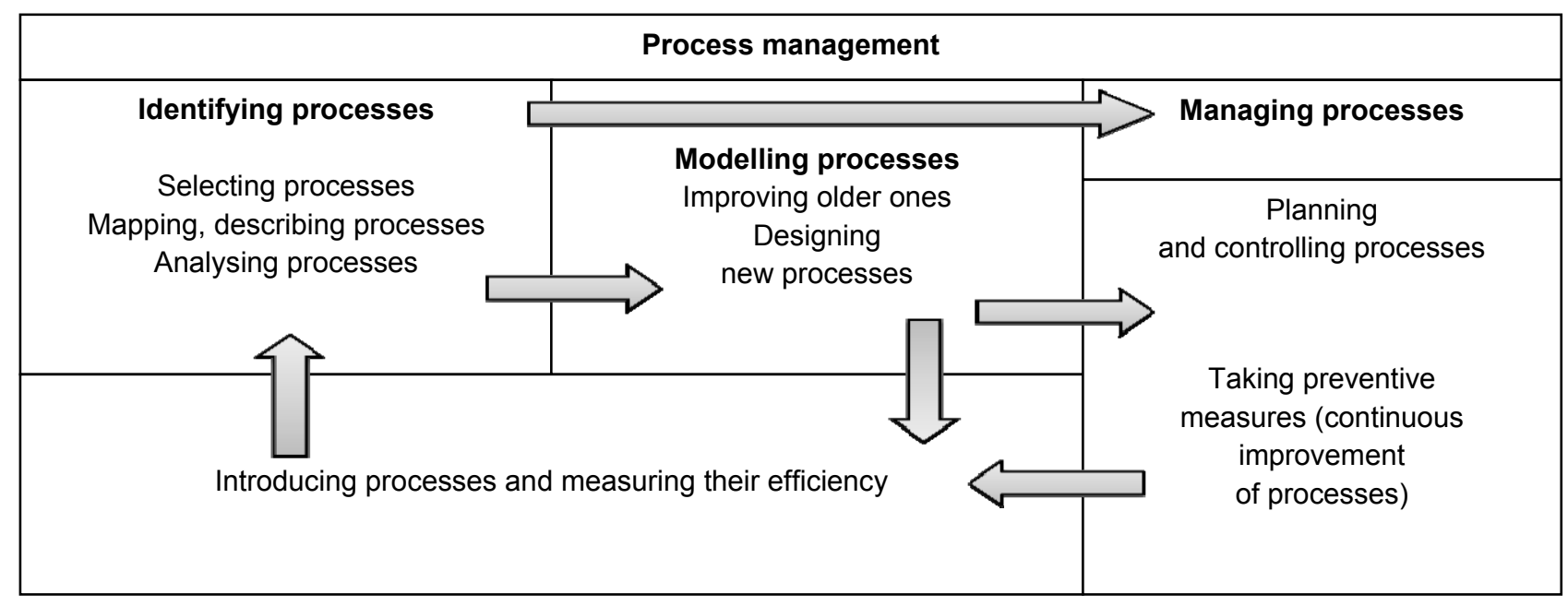

Figure 1. A process management diagram (source: [8, p. 186]) 
The aim of process management is to:

- reduce the duration of processes,

- reduce costs of processes,

- increase the quality of the processes and of products/services,

- increase the productivity of employees,

- strengthen the competitive advantage.

The idea of process management has many advantages, among which can be mentioned:

- it is better than the conventional description of the organisation's activities,

- a greater ability to assess and influence the effectiveness of the entire organisation, in particular its clearly separated parts of processes,

- the process description of the organisation makes it easier for the employees to explore the operation (the reference process) with a parallel, optimistic prospect of their own impact on the results achieved,

- greater predictability of behaviour of employees strongly motivated to achieving results in all areas of the organisation's activities, and not only in those that are verified by external customers' expectations,

- a potentially big opportunity to reduce the cost of the organisation's activities through very flexible forms of using all the resources of the organisation, including human resources,

- a significantly higher level of operational flexibility than in a functionally, classically configured organisation - achieved by the high level of responsiveness to expectations of customers,

- a potentially positive impact of the process-based organisational system on the learning and the development of both employees and the entire organisation [1, p. 39].

The entry point for process management is to identify the processes to determine what processes are needed in the organisation so that customers receive the expected product/service. For each process, there should be targets set for its implementation, taking into account the objectives of the organisation as well as customers' requirements.

\section{The concept of insurance business process decomposition}

The purpose of the business of insurance is to provide specific insurance related to the offering and granting protection against the risk of the effects of random events [15, Art. 3 point 1]. The activities of insurance companies as well as of other organisations operating in a competitive market is focused on the customer's needs and satisfaction, as shown in Fig. 2.

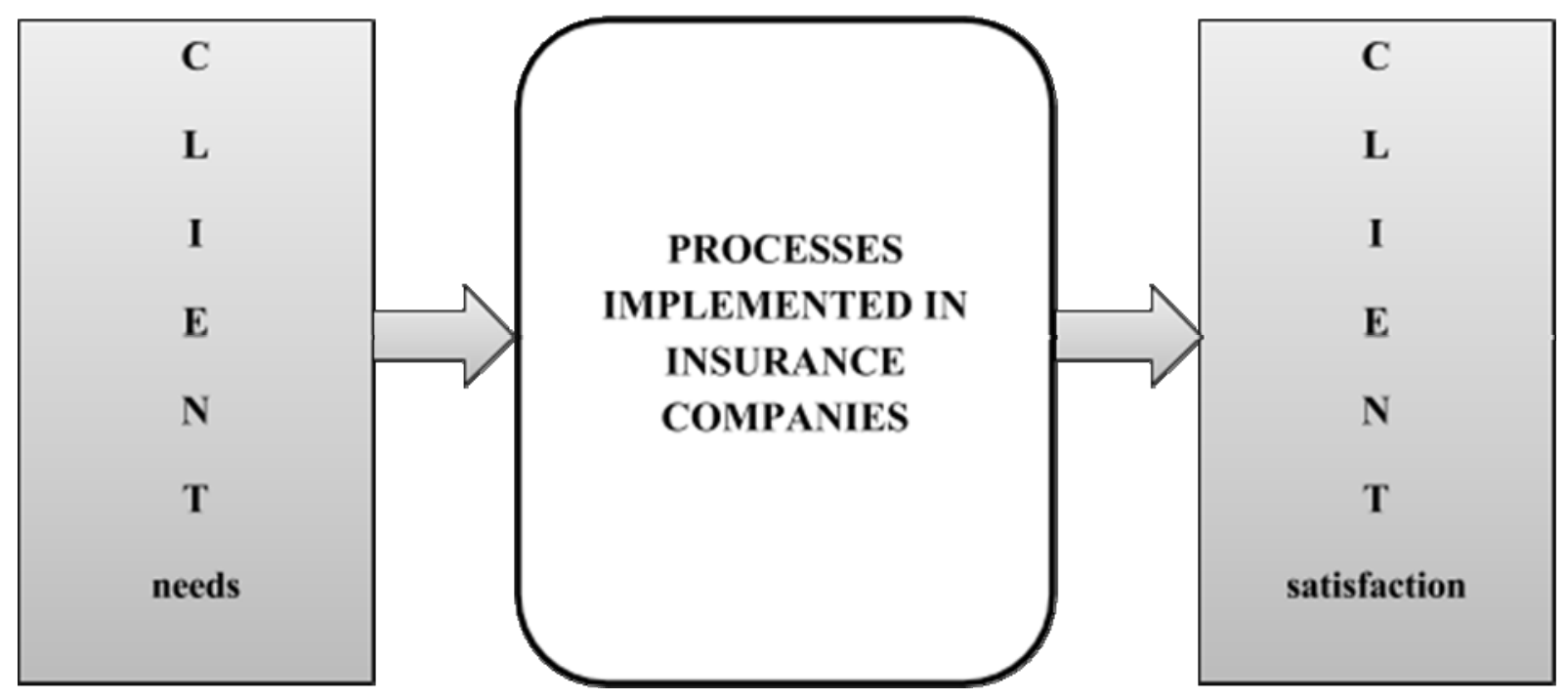

Figure 2. Market orientation of insurance companies (source: [4]) 
The issues of a process-based approach to the business of insurance are usually neglected in the numerous publications on insurance. The only exceptions are the works of A. Karmańska [6], A. Karmańska, K. Kędziora and M. Lament [7] and L. Gąsiorkiewicz $[3,4]$. A. Karmańska, for the purposes of modelling the activity-based costing, singled out the following processes carried out in the framework of the insurance business:

- marketing,

- sales of insurance products,

- reinsurance of insured risk,

- management of insurance fund deposits,

- process of compensation or benefits and recourse proceedings,

- preventive process,

- administering the collections of insurance statistics,

- process of managing finance,

- human resource management,

- managing insurer's infrastructure and regional network.

Then, the author presents a functional map of the decomposition of the insurance company, highlighting the first, second and third degree processes and auxiliary processes. According to A. Karmańska, the insurer is justified to use the gradation of operational processes and singling out processes at the interface between the insurer, the customer, and the processes in the background of this relationship.

First-degree (primary) processes include:

- marketing,

- selling insurance products,

- compensation.

Second degree (secondary) processes include:

- insured risk reinsurance,

- insurance company's investment management,

- prevention,

while third degree processes include:

- administering the collections of insurance statistics.

The auxiliary processes are: human resource management, financial management, and managing the regional network.

A. Karmańska, K. Kędziora, M. Lament - for the needs of financial accounting, distinguish the following processes:
- sales of insurance products,

- compensation and benefits and recourse proceedings,

- reinsuring insured risks,

- managing the insurance company's investments,

- financial management.

The processes highlighted by the authors are part of the processes listed by A. Karmańska, and the subprocesses are identical. The authors do not specify in their work the criteria according to which they made the division of the processes.

According to the author of this study, the processes carried out at insurance companies can be divided into three groups, namely: the primary, secondary and the management (general) processes. The primary processes are those related to the primary task of insurance companies, as specified in the Insurance Activity Act (providing insurance cover). These include insurance agreements and - in case of occurrence of an event specified in the contract - the liquidation of damages.

Secondary processes are processes that support the implementation of the primary processes. Thanks to this support, the primary processes can produce the expected results. 'The products' of these processes are often not visible to external clients, but have a significant impact on the financial management of insurance companies.

Management (general) processes are processes designed to ensure the effective planning and operation of the primary and secondary processes, and the effective management of the insurance company.

A decomposition of the processes carried out in the insurance companies is presented in Fig. 3.

The objectives of the insurance business processes are presented in Table 2.

The decomposition process of insurance business:

- is better than the conventional description of the organisation's activities,

- gives a greater ability to assess and influence the effectiveness of the entire organisation, in particular its clearly separated parts of processes,

- makes it easier for the employees to explore the operation (the reference process) with a parallel, optimistic prospect of their own impact on the results achieved, 


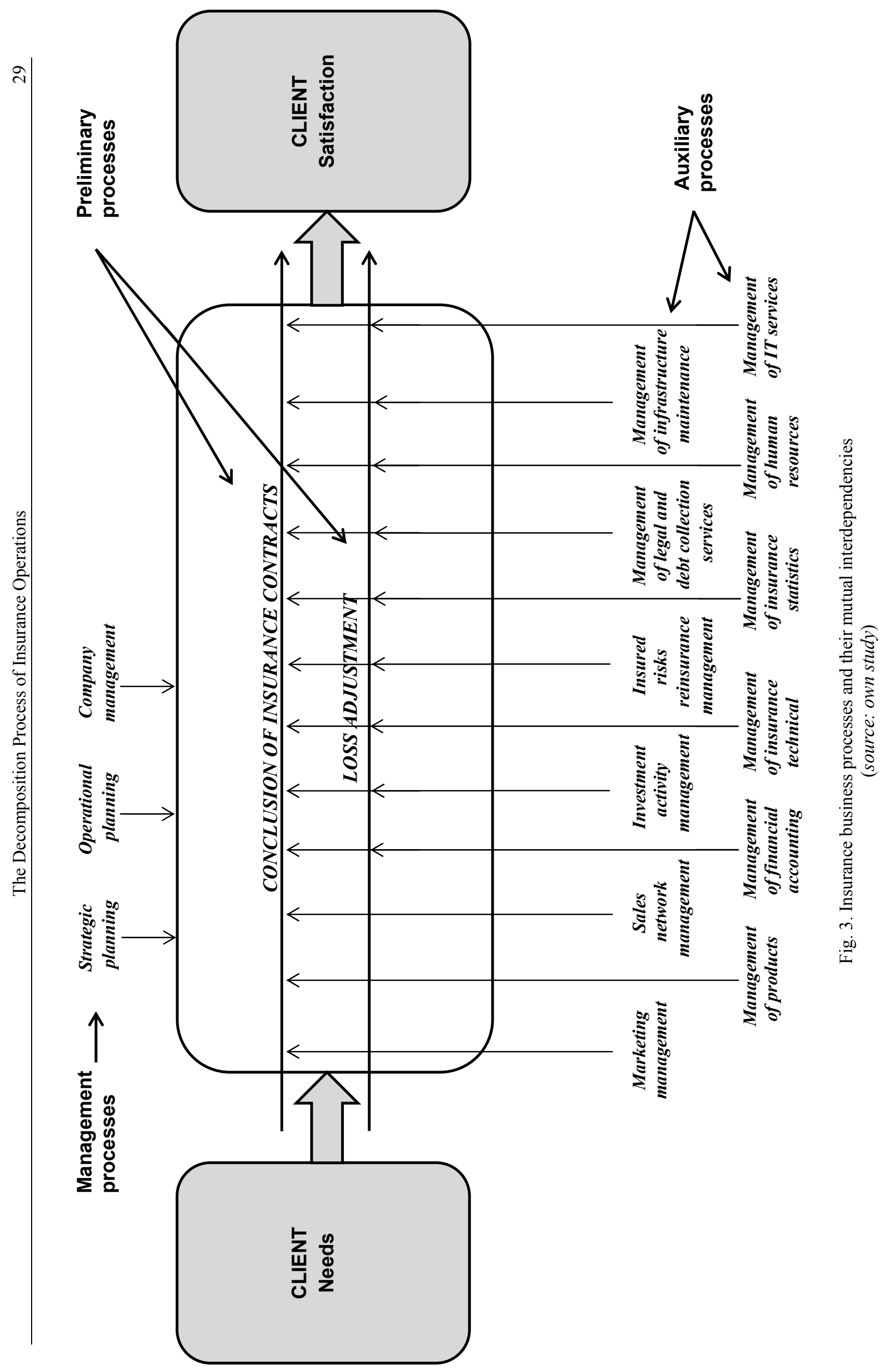


Table 2. The objectives of the insurance business processes (source: own study)

\begin{tabular}{|c|c|}
\hline Process & The objective of the process \\
\hline $\begin{array}{l}\text { Conclusion of insurance } \\
\text { contracts }\end{array}$ & $\begin{array}{l}\text { Acquiring a premium from current and future customers in accordance } \\
\text { with the strategic objectives of the insurance company }\end{array}$ \\
\hline Loss adjustment & $\begin{array}{l}\text { Deciding the scope of liability, and the amount of compensation adequate to the extent } \\
\text { of the damage, in accordance with the requirements of laws and internal regulations } \\
\text { of the insurance company and the settlement of claims ending with the payment } \\
\text { of compensation / benefits due }\end{array}$ \\
\hline Marketing management & $\begin{array}{l}\text { Planning and implementing marketing activities to support the implementation } \\
\text { of the sales and image building objectives of the insurance company. }\end{array}$ \\
\hline Product management & $\begin{array}{l}\text { Optimisation of the product offer tailored to the current and future needs of customers, } \\
\text { according to the strategic objectives of the insurance company }\end{array}$ \\
\hline Managing the sales network & Organisation and maintenance of an optimal insurance products sales network \\
\hline Financial accounting & $\begin{array}{l}\text { Providing timely and correct records of business events, as well as providing financial } \\
\text { reporting and the timely payment of financial obligations of the insurance company }\end{array}$ \\
\hline $\begin{array}{l}\text { Investment activity } \\
\text { (investment deposits) }\end{array}$ & $\begin{array}{l}\text { Achieving a high return on investment at a given level of risk, taking into account } \\
\text { the need to ensure the liquidity of cash }\end{array}$ \\
\hline Technical provisions & $\begin{array}{l}\text { Financial security of current and future liabilities of the insurance company toward } \\
\text { customers arising from insurance contracts }\end{array}$ \\
\hline Reinsurance of insured risks & $\begin{array}{l}\text { Ensuring the financial security of the insurance company by dispersing the insurance } \\
\text { risk (increasing the insurance capacity, the stabilising the performance of the insurance } \\
\text { company and protecting against catastrophic risk) }\end{array}$ \\
\hline Insurance statistics & Creating an internal system of reporting on insurance activities \\
\hline $\begin{array}{l}\text { Legal support and debt } \\
\text { collection services }\end{array}$ & $\begin{array}{l}\text { Ensuring uniform principles of legal support and debt collection services } \\
\text { of the company and its regional units }\end{array}$ \\
\hline $\begin{array}{l}\text { Human resource } \\
\text { management }\end{array}$ & $\begin{array}{l}\text { Selection of employees with optimal qualifications for the position and for the } \\
\text { implementation of an incentive and remuneration policy of the insurance company }\end{array}$ \\
\hline $\begin{array}{l}\text { Information technology } \\
\text { support }\end{array}$ & $\begin{array}{l}\text { Needs analysis and implementation of projects and maintenance of the IT infrastructure } \\
\text { of the insurance company }\end{array}$ \\
\hline Infrastructure maintenance & $\begin{array}{l}\text { Needs analysis and securing the fixed assets and insurance forms necessary } \\
\text { for the operations of the insurance company }\end{array}$ \\
\hline
\end{tabular}

- allows an opportunity to reduce the cost of the organisation's activities through very flexible forms of using all the resources of the organisation, including human resources,

- provides a significantly higher level of operational flexibility than in a functionally, classically configured organisation - achieved by the high level of responsiveness to expectations of customers,

- brings a better understanding of the processes of decision-making in the financial management of insurance companies.
A further part of the paper presents the cash flows using the example of one of the primary processes, namely the process of concluding insurance contracts.

\section{$4 \quad$ Analysis of financial flows in the process of concluding insurance contracts}

The process of concluding insurance contracts, from the point of view of financial management, can be broken down the following actions, as shown in Fig. 4. 


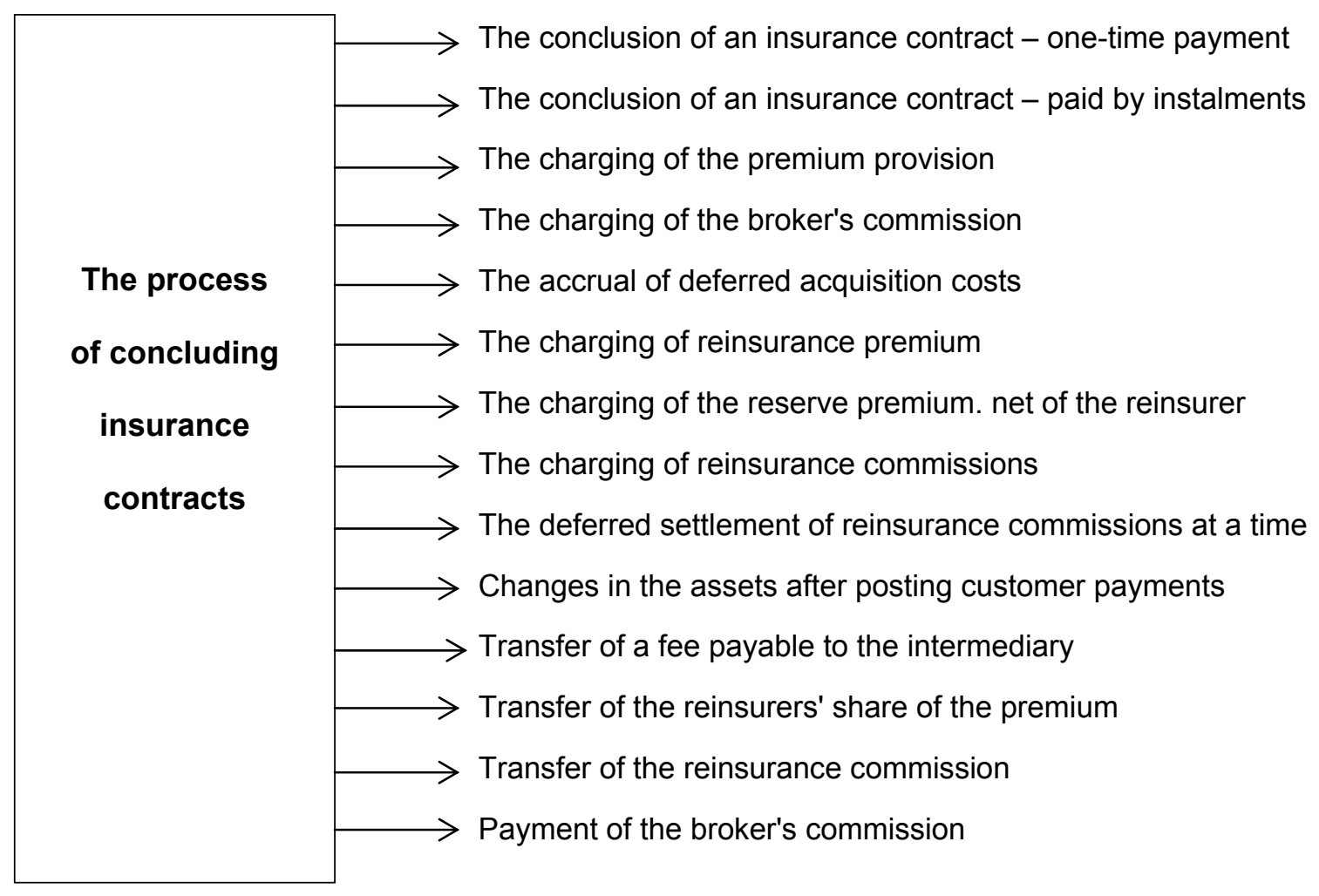

Figure 4. Activities carried out in the process of concluding insurance contracts (source: own study)

The process of concluding insurance contracts has a multi-directional impact on the financial performance of insurance companies. This applies both to activities carried out in the process, as well as to the costs associated with the implementation of the process. The values of assets and liabilities change, as do the positions of the insurance technical account and of the profit and loss account. This causes changes in the financial performance of insurance companies. A model of financial flows in the process of concluding insurance contracts is shown in Fig. 5.

\section{Legend:}

1 - the conclusion of an insurance contract - a onetime payment,

2 - the conclusion of an insurance contract - payment by instalments,

3 - the charging of the premium provision,

4 - the charging of the broker's commission,

5 - the accrual of the deferred acquisition costs,
6 - the charging of the reinsurance premium (proportional reinsurance),

7 - the charging of the reserve premium, net of the reinsurer,

8 - the calculation of the reinsurance commissions,

9 - the deferred settlement of reinsurance commissions at a time,

10 - the costs of implementing the process of concluding insurance contracts,

11 - posting customer payments,

12 - transfer of a fee payable to the intermediary,

13 - transfer of the reinsurers' share of the premium,

14 - transfer of the reinsurance commission,

15 - payment of the broker's commission,

16 - transfer of the technical result to the general profit and loss account,

17 - transfer of net profit (loss) attributable to the liabilities. 


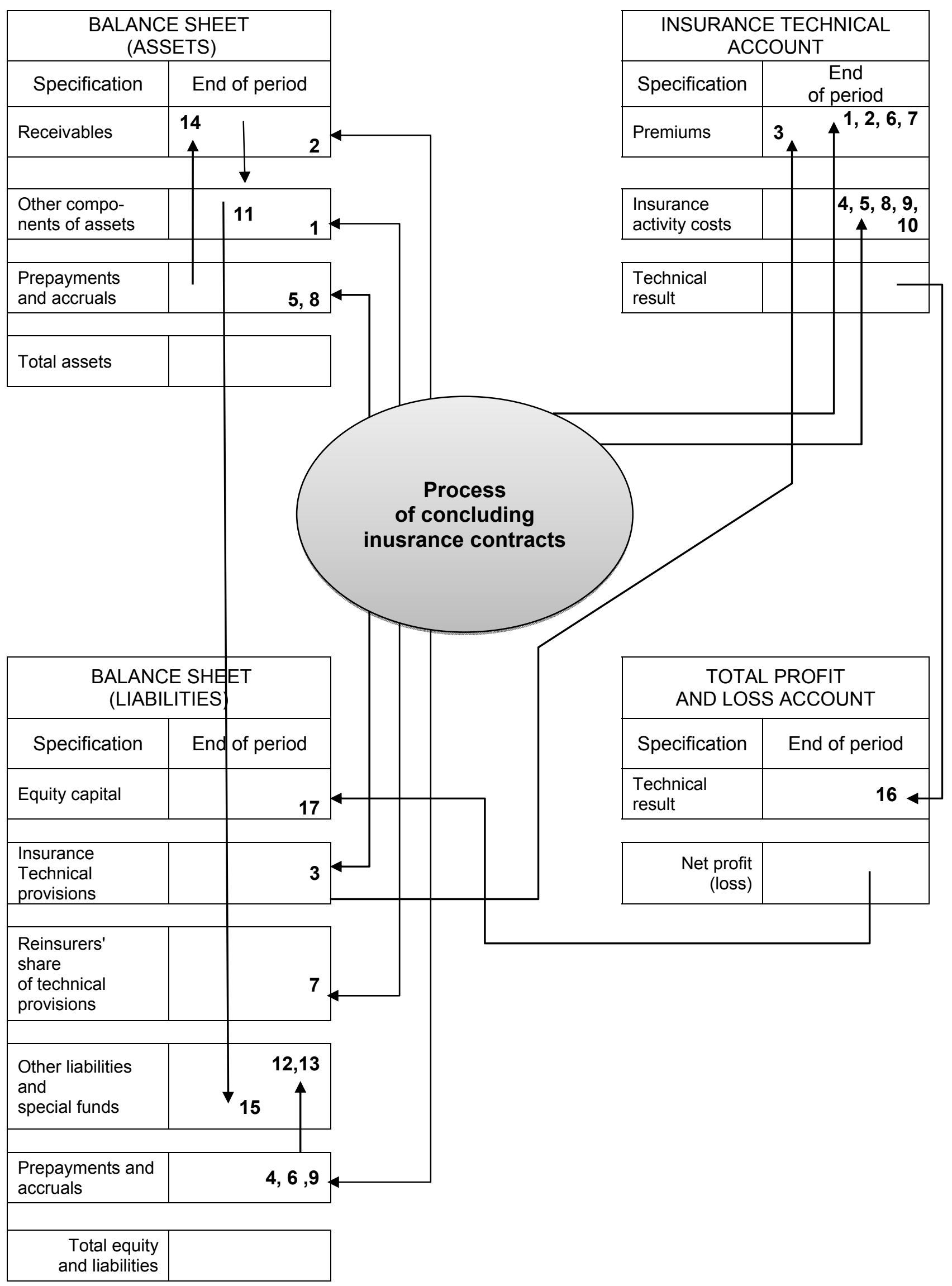

Figure 5. Model of financial flows in the process of concluding insurance contracts (source: [4]) 
Table 4. The impact of the activities carried out in the process of concluding insurance contracts on the formation of the balance sheet, the insurance technical account and the general profit and loss account

(source: own study)

\begin{tabular}{|c|c|c|c|}
\hline Activity & Balance sheet & $\begin{array}{c}\text { Insurance technical } \\
\text { account }\end{array}$ & $\begin{array}{c}\text { General profit and loss } \\
\text { account } \\
\end{array}$ \\
\hline $\begin{array}{l}\text { The conclusion of an insurance } \\
\text { contract - a one-time payment }\end{array}$ & $\begin{array}{c}\text { Raises the sum of assets } \\
\text { and liabilities }\end{array}$ & $\begin{array}{l}\text { Improves the technical } \\
\text { result }\end{array}$ & Improves earnings \\
\hline $\begin{array}{c}\text { The conclusion of an insurance } \\
\text { contract - payment by instal- } \\
\text { ments }\end{array}$ & $\begin{array}{c}\text { Raises the sum of assets } \\
\text { and liabilities }\end{array}$ & $\begin{array}{l}\text { Improves the technical } \\
\text { result }\end{array}$ & Improves earnings \\
\hline The charging of the premium & $\begin{array}{l}\text { It does not change the } \\
\text { total assets and liabilities }\end{array}$ & $\begin{array}{l}\text { Worsens the technical } \\
\text { result }\end{array}$ & Worsens earnings \\
\hline $\begin{array}{l}\text { The charging of the broker's } \\
\text { commission }\end{array}$ & $\begin{array}{l}\text { It does not change the } \\
\text { total assets and liabilities }\end{array}$ & $\begin{array}{l}\text { Worsens the technical } \\
\text { result }\end{array}$ & Worsens earnings \\
\hline $\begin{array}{l}\text { The accrual of deferred acquisi- } \\
\text { tion costs }\end{array}$ & $\begin{array}{l}\text { Raises the sum of assets } \\
\text { and liabilities }\end{array}$ & $\begin{array}{l}\text { Improves the technical } \\
\text { result }\end{array}$ & Improves earnings \\
\hline $\begin{array}{c}\text { The charging of reinsurance } \\
\text { premium }\end{array}$ & $\begin{array}{l}\text { It does not change the } \\
\text { total assets and liabilities }\end{array}$ & $\begin{array}{l}\text { Worsens the technical } \\
\text { result }\end{array}$ & Worsens earnings \\
\hline $\begin{array}{l}\text { The charging of the reserve } \\
\text { premium, net of the reinsurer }\end{array}$ & $\begin{array}{l}\text { It does not change the } \\
\text { total assets and liabilities }\end{array}$ & $\begin{array}{l}\text { Improves the technical } \\
\text { result }\end{array}$ & Improves earnings \\
\hline $\begin{array}{l}\text { The charging of reinsurance } \\
\text { commissions }\end{array}$ & $\begin{array}{c}\text { Raises the sum of assets } \\
\text { and liabilities }\end{array}$ & $\begin{array}{l}\text { Improves the technical } \\
\text { result }\end{array}$ & Improves earnings \\
\hline $\begin{array}{l}\text { The deferred settlement of rein- } \\
\text { surance commissions at a time }\end{array}$ & $\begin{array}{l}\text { It does not change the } \\
\text { total assets and liabilities }\end{array}$ & $\begin{array}{l}\text { Worsens the technical } \\
\text { result }\end{array}$ & Worsens earnings \\
\hline $\begin{array}{l}\text { Changes in the assets after } \\
\text { posting customer payments }\end{array}$ & $\begin{array}{l}\text { Assets items are changed } \\
\text { without changing the total } \\
\text { assets }\end{array}$ & $\begin{array}{l}\text { They do not change the } \\
\text { technical result }\end{array}$ & No change in earnings \\
\hline $\begin{array}{c}\text { Transfer of a fee payable to the } \\
\text { intermediary }\end{array}$ & $\begin{array}{c}\text { Changes liability items } \\
\text { without changing the total } \\
\text { liabilities }\end{array}$ & $\begin{array}{l}\text { It does not change the } \\
\text { technical result }\end{array}$ & No change in earnings \\
\hline $\begin{array}{l}\text { Transfer of the reinsurers' share } \\
\text { of the premium }\end{array}$ & $\begin{array}{c}\text { Changes liability items } \\
\text { without changing the total } \\
\text { liabilities }\end{array}$ & $\begin{array}{l}\text { It does not change the } \\
\text { technical result }\end{array}$ & No change in earnings \\
\hline $\begin{array}{l}\text { Transfer of the reinsurance } \\
\text { commission }\end{array}$ & $\begin{array}{c}\text { Assets items are changed } \\
\text { without changing the total } \\
\text { assets }\end{array}$ & $\begin{array}{l}\text { It does not change the } \\
\text { technical result }\end{array}$ & No change in earnings \\
\hline $\begin{array}{l}\text { Payment of the broker's com- } \\
\text { mission }\end{array}$ & $\begin{array}{c}\text { Reduces the total assets } \\
\text { and liabilities }\end{array}$ & $\begin{array}{l}\text { It does not change the } \\
\text { technical result }\end{array}$ & No change in earnings \\
\hline
\end{tabular}

The impact of the activities carried out in the process of concluding insurance contracts on the formation of the balance sheet, the insurance technical account and the general profit and loss account is presented in Table 4.

The analysis of financial flows, of a sample process shows that the decomposition process of insurance business creates conditions that significantly improve the monitoring of the financial situation of an insurance company. It enables a thorough analysis of the impact of individual processes - and activities implemented as part of them - on the financial results of insurance companies and enables appropriate actions to be taken in this regard. 


\section{Conclusion}

The use of a process-based approach results in the perception of the insurance company as a dynamic organisation with a number of processes aimed at achieving certain objectives. This perception of insurance companies can improve the efficiency and effectiveness of their actions and also fosters:

- the transparency of the insurance company,

- consistency of the objectives of individual processes with customers' expectations,

- identification with the decisions taken,

- participation and involvement of the implementation personnel in the operations area of each process,

- identification of bottlenecks. elimination of duplications of effort,

- shortening and simplifying the processes occurring in the insurance company,

- optimisation of operations,

- reducing the costs of operations,

- defining the powers and responsibilities.

\section{Bibliography}

[1] Bitkowska A., Kolterman K., Wójcik G., Wójcik K. - Zarzadzanie procesami w przedsiębiorstwie. Aspekty teoretyczno - praktyczne (Process Management in an Enterprise. Theoretical and Practical Aspects). Difin, Warsaw 2011.

[2] Brilman J. - Nowoczesne koncepcje i metody zarzadzania (Modern Management Concepts and Methods). PWE, Warsaw 2002.

[3] Gąsiorkiewicz L. - Finanse zakładów ubezpieczeń majatkowych. Theory and practice (Finance of Life Insurance Companies. Theory and Practice). CH Beck, Warsaw 2009.

[4] Gąsiorkiewicz L. - Zarządzanie gospodarka finansowa zakładów ubezpieczeń ujęcie procesowe (Managing Finance in Insurance Companies Process-Based Approach). Poltext Publishers, Warsaw 2014.

[5] Grajewski P. - Organizacja procesowa. Projektowanie i konfiguracja (The Process-Based Organisation. Design and Configuration). PWE, Warsaw 2007.
[6] Karmańska A. - Rachunkowość zarzadcza ubezpieczyciela. Modelowanie na podstawie rachunku kosztów działań (Managing Insurer's Accounting. Activity Costs Account-Based Modelling). PWN Polish Scientific Publishers, Warsaw 2003.

[7] Karmańska A., Kędziora K., Lament M. - Rachunkowość finansowa zakładów ubezpieczeń (Financial Accounting in Insurance). Difin, Warsaw 2003.

[8] Nowosielski S. - Modelowanie procesów gospodarczych $w$ literaturze i praktyce (Business Processes Modelling in the Literature and in Practice) [in] Podejście procesowe $w$ organizacjach (Process-Based Approach in Organisations) (scientific ed. S. Nowosielski). Prace naukowe Uniwersytetu Ekonomicznego we Wrocławiu (Scientific Works of the University of Economics in Wrocław), Wrocław University of Economics Publishing House, Wrocław 2009.

[9] Nowosielski S. - Procesy i projekty logistyczne (Logistics Processes and Projects). Wrocław University of Economics Publishing House Wrocław. 2008.

[10] Perechuda K. (ed.) - Zarzqdzanie przedsiębiorstwem przyszłości - koncepcje. modele. metody (Managing a Business of the Future - Concepts. Models. Methods). Placet, Warsaw 2000.

[11] Porter M. - Competitive Advantage. Free Press, New York 1985.

[12] Pszczółkowski T. - Mała encyklopedia prakseologii $i$ teorii organizacji (A Small Encyclopedia of Praxeology and Organisation Theory). Ossolineum, Warsaw - Wrocław 1978.

[13] Romanowska M., Trocki M. (ed.) - Podejście procesowe $w$ zarzqdzaniu (The Proces-Based Approach in Management). Vol. 1, Warsaw School of Economics, Warsaw 2004.

[14] Skrzypek E., Hofman M. - Zarzadzanie procesami $w$ przedsiębiorstwie (Process Management in an Enterprise). Wolters Kluwer Polska Publishing House, Warsaw 2010.

[15] The Insurance Activity Act of 22 May 2003. Journal of Laws of 2003, No. 124, item 1151.

[16] Zieleniewski J. - Organizacja zespołów ludzkich. Wstep do teorii organizacji i kierowania (The Organisation of Human Teams. Introduction to the Theory of Organisation and Management). PWN, Warsaw 1976. 